\title{
3rd ICTs and Society Meeting; Paper Session - Inequalities: social, economic, political; Paper 1: Information Society Policies 2.0. A Critical Analysis of the Potential and Pit- falls of Social Computing \& Informatics in the Light of E- inclusion
}

\author{
Pieter Verdegem
}

Research Group for Media \& ICT (IBBT-MICT), Ghent University (UGent), Interdisciplinary Institute for Broadband Technology (IBBT) (Pieter.Verdegem@UGent.be)

\begin{abstract}
In this paper we reflect on how research and policies can and/or should help in the development of a sustainable information society for all. More specifically, we critically investigate how social computing \& informatics can entail both potential and pitfalls, especially with regard to the difficult relationship between digital and social inclusion. First of all, traditional information society policies are scrutinized. Furthermore, we point at the existence of digital inequalities and we reflect briefly on policy intervention on this (e-inclusion). In addition, we also evaluate the raise of social computing \& informatics. Finally, attention is given to the challenge of how research can contribute to the participation of all in the information society.
\end{abstract}

Keywords: Information society policies, digital inequalities, social computing \& informatics, digital and social inclusion

\section{Intro \& context}

The increasing dependence on ICT in everyday life, both in our professional and private lives, forces us to reflect on how we can manage the digital era. Policymakers are actively involved in exploring conditions on how to take optimal benefit of the new opportunities offered by ICT.

Traditional policies do not only reflect a techno-enthusiastic vision on the information society \& knowledge economy. The existence of digital inequalities - more well-known as 'the digital divide' - is according to several (mainly scholarly) observers also a clear illustration that information society policies suffer from technological determinism (Garnham, 2000; Golding, 2000; Goodwin \& Spittle, 2002; May, 2002). The latter refers to visions that consider ICT as the most important driver of the increase in societal prosperity, enabling the global use of new communication technologies that will eventually lead to a massive social and economical transformation.
The techno-economic focus has clearly dominated the first generation of information society policies. In this context, the concept of 'knowledge economy' is often used (Jessop, 2005). On the other hand, the concept of 'information society' mainly deals with sociocultural impacts (Martin, 2005). Following the techno-economic paradigm, the establishment of a knowledge-based economy became the goal in itself (Freeman \& Perez, 1998). Research \& Development (R\&D) is a key term in such conceptions and this would lead to technological progress and economic growth.

In academia, however, a strong plea is made for more thoughtful approaches of ICT in policy discussions (Mansell, 2008). In this perspective, Manuel Castells' vision on the network society is particularly important to mention. Inclusion in the network(s) is a necessary condition to be able to participate in our society. According to Castells, providing access to ICT must be seen as a right of citi- 
zenship in the information age. However, he cautions for the influence of informational capitalism (Castells, 1996; Fuchs, 2008). A crucial social cleavage concerns those pushed to the margins of informational capitalism: the unskilled and educationally illprepared (Webster, 2006).

Despite the dominance of 'hard' economic objectives in policy visions on the information society, an important role also seems to be defined for processes that indirectly contribute to this. Therefore, in the early (neoliberal) discourse of the European Commission (Servaes \& Burgelman, 2000) the aim for a better performing knowledge economy is linked with the striving for more social cohesion. E-inclusion can be seen as policy intervention in order to reduce digital inequalities. Therefore, it is part of broader policy measures that aim to include all citizens in society and to foster social cohesion (Cammaerts et al., 2003; Mansell, 2002). According to the European Commission (2001), e-inclusion consists of two dimensions: Firstly, it focuses on preventing digital exclusion. This means that policy measures should prevent that (socially) disadvantaged groups are left behind in the development of the information society. Secondly, e-inclusion is about exploiting new opportunities for a better inclusion of socially disadvantaged people or groups, or lessfavoured areas.

In policy discussions on e-inclusion a major point of attention is the active involvement in society. In other words, e-inclusion is basically social inclusion in the knowledge society. Therefore, beyond access to ICT tools and services, beyond even digital literacy, a definition of e-inclusion should focus on people's empowerment and participation in the knowledge society and economy: skills \& competences, awareness \& willingness, social capital and the means to grow should also be key factors of e-inclusion (Kaplan, 2005).

Social computing \& informatics (Pascu et al., 2008; Kling et al., 2005) - and a broader movement that is commonly named as Web 2.0 and social media (Fuchs, 2008; Hassan \& Thomas, 2006) - may be function as a lever to better support the role of active involvement and user empowerment, especially because the user is given a more central role in com- parison with 'traditional' ICT and media technologies. Therefore, the impact of social computing \& informatics may be understood as a first sign of societal re-engineering, as it marks a fundamental shift from technology driven innovation towards user and society driven innovation. This way, the technological deterministic approach of the information society (also in policies) may be challenged.

\section{Challenges for research (and policy)}

\subsection{Social inclusion versus digital inclu- sion}

Digital access and capabilities in dealing with ICT have been identified as relevant for personal fulfillment and development, active citizenship, social inclusion and employment (van Dijk, 2005; Warschauer, 2003). Besides avoiding the emergence of new inequalities, digital inclusion contributes to social inclusion to the extent that people at risk of exclusion can be empowered through ICT. Social computing \& informatics may support the enhancement of citizens' social capital as it enables interactions between offline and online sociability and the enrichment of social relations by creating and maintaining links through the use of social networks. In addition, social computing \& informatics can also contribute to the development of cultural capital of disadvantaged people as it broadens the access to digital content and other opportunities which facilitate (informal) learning processes (Ala-Mutka et al., 2009).

Nowadays, social computing \& informatics present a double face: it can possibly create new digital divides widening the gap created by digital and social exclusion for already vulnerable groups and people. Simultaneously it can also be an enabler of self-organization (Fuchs, 2008) and self-help processes started by, or involving, socially-excluded people, that transform weak ties created across the online and offline worlds into effective collective structures of engagement and participation. Summarizing, in our research activities we should strive to better understand (including empirical evidence) how the potential of social computing \& informatics can support user participation and user empowerment without cre- 
ating new inequalities, both on the digital and on the social level.

\subsection{The need of (new) theoretical frameworks}

Given new developments and emerging societal trends (e.g. the success of social computing \& informatics), it is clear that we need new theoretical frameworks that can support our analysis. In view of this, Castells (2009) has introduced in his 'Communication Power' a new concept that will shape the (trans)disciplinary discussions in this field. The concept 'mass self-communication' refers to both mass communication because it can potentially reach a global audience, and to self-communication because the message is self-generated, self-directed and self-selected.

The concept provides an interesting framework for studying new power relations in the digital era and for investigating how the disruptive potential of technology can be employed for better social inclusion. However, one could question whether the problem of the digital divide and the lack of digital skills among (a part of) the population of Internet users, are not ignored by Castells. The (possible) liberating potential of mass selfcommunication can be seen in another light when Internet use would lead to a reinforcement of the 'information elite' and big problems to catch up for large parts of the population. We need thus to continue in critically assessing the theoretical frameworks that can help in studying the field.

\subsection{Challenges on the empirical level}

Another question deals with the empirical approaches of our research in this field. Given the double face of social computing \& informatics we could argue to specifically focus on disadvantaged groups. On the other hand, it remains unclear whether this label accurately fits with different categories of user participation and/or usage divides (Pascu et al., 2008).

Our methodological toolkit at hand should also be critically evaluated. When it comes to the measurement and monitoring of digital skills and/or social \& cultural capital, it is clear that a single-method approach may be not sufficient at all. We should consider to implement new and emerging methods such as ethnography and other user-centric research techniques.

Last but not least, the methodologies that are employed in the research should have close links with well-considered conceptual frameworks. More specifically, we should invest in better defining and trashing out (vague) concepts such as social computing \& informatics, user participation and user empowerment.

\subsection{Towards policy-oriented action re- search?}

More in general, another central question deals with the role of researchers in the process of policymaking. What is, can and should be our contribution in this? Should we just be 'neutral' observers (with a main focus on describing and explaining the complex reality) or is it our duty to (try to) really hold policymakers responsible for establishing a society that enables and encourages real participation of all citizens?

\section{References}

Ala-Mutka, K., Broster, D., Cachia, R., Centeno, C., Feijóo, Haché, A., Kluzer, S., Lindmark, S., Lusoli, W., Misuraca, G., Pascu, C., Punie, Y. \& Valverde, J.A. (2009). The impact of social computing on the EU information society and economy. Luxembourg: Office for Official Publication of the European Communities.

Castells, M. (1996). The rise of the network society. Oxford: Blackwell.

Castells, M. (2009). Communication power. Oxford, New York: Oxford University Press.

European Commission (2001). E-inclusion: The information society's potential for social inclusion in Europe. Retrieved 12/06/2010 from: http://ec.europa.eu/employment social/knowledge society/docs/eincl en.pdf. 
Freeman, C., \& Perez, C. (1988). Techno-economic paradigm. In G. Dosi (Ed.), Technical change and economic theory. London: Pinter Publishers.

Fuchs, C. (2008). Internet and society. Social theory in the information age. New York \& London: Routledge.

Garnham, N. (2000). 'Information society' as theory or ideology: A critical perspective in technology, education and employment in the information age. Information, Communication and Society, 3(2), 139-152.

Golding, P. (2000). Forthcoming features: Information and communication technologies and the sociology of the future. Sociology, 34(1), 165-184.

Goodwin, I., \& Spittle, S. (2002). The European Union and the information society: Discourse, power and policy. New Media and Society, 4(2), 225-249.

Hassan, R. \& Thomas, J. (2006). The new media reader: A critical introduction. London \& New York: Routledge.

Jessop, B. (2005). Cultural political economy, the knowledge-based economy, and the state. In D. Slater \& A. Barry (Eds.) The technical economy (pp. 144-166). London: Routledge.

Kaplan, D. (2005). E-inclusion: new challenges and policy recommendations. eEurope Advisory Group - Working Group 2 e-Inclusion: Final report. Retrieved 16/06/2010 from: http://www.epractice.eu/files/media/media 764.pdf.

Kling, R., Rosenbaum, H. \& Sawyer, S. (2005). Understanding and communicating social informatics. Medford, NJ: Information Today.

Mansell, R. (2002). From digital divides to digital entitlements in knowledge societies. Current Sociology, 50(3), 407-426.

Mansell, R. (2008). The life and times of the information society: A critical review. Paper presented at the Fifth Anniversary Conference of the Department of Media and Communication, 'Media, Communication \& Humanity', London School of Economics and Political Sciences.

Martin, B. (2005). Information society revisited: From vision to reality. Journal of Information Science, 31(1), 4-12.

May, C. (2002). The information society: A sceptical view. Cambridge, UK: Polity Press.

Pascu, C., Osimo, D., Turlea, G., Ulbrich, M., Punie, Y., \& Burgelman, J. C. (2008). Social computing: Implications for the EU innovation landscape. Foresight, 10(1), 37-52.

Servaes, J., \& Burgelman, J. C. (2000). In search of a European model for the information society. Telematics and Informatics, 17(1-2), 1-7.

van Dijk, J. (2005). The deepening divide: Inequality in the information society. London: Sage.

Warschauer, M. (2003). Technology and social inclusion: Rethinking the digital divide. Cambridge: MIT Press.

Webster, F. (2006). Theories of the information society (third edition). London \& New York: Routledge.

\section{About the Author}

Pieter Verdegem

Pieter Verdegem, Ph.D. is a senior researcher at the Research Group for Media \& ICT (IBBT-MICT), Ghent University (UGent). He is also affiliated to the Interdisciplinary Institute for Broadband Technology (IBBT). His research focuses on ICT acceptance, information society, ICT policy, e-government and e-inclusion. He holds a master's degree in Communication Sciences and in E-communications Studies. In 2009, Pieter obtained a Ph.D. focusing on government strategies in the information society, particularly e-government and e-inclusion. 